\title{
Digital Geologic Cartography and Geochronologic Database of the Trans-Mexican Volcanic Belt and Adjoining Areas
}

\section{Cartografía Geológica Digital y Base de Datos Geocronológica del Cinturón Volcánico Transmexicano y Áreas Contiguas}

\author{
Luca Ferrari*a, Teresa Orozco Esquivel ${ }^{\mathrm{a}}$, Mario Navarro ${ }^{\mathrm{a}}$, Penélope López-Quiroz ${ }^{\mathrm{a}}$, Laura Luna ${ }^{\mathrm{b}}$ \\ ${ }^{a}$ Centro de Geociencias, Universidad Nacional Autónoma de México, Campus UNAM Juriquilla, Queretaro, 76230, Mexico \\ ${ }^{b}$ Instituto de Geología, Universidad Nacional Autónoma de México, Ciudad Universitaria, México City, 04510, Mexico
}

\begin{abstract}
We present the first interactive digital geologic map of the Trans-Mexican Volcanic Belt (TMVB). The area covered by the cartography span $10^{\circ}$ of Longitude $\left(106^{\circ}-96^{\circ} \mathrm{W}\right)$ and $2^{\circ} 45^{\prime}$ of Latitude $\left(19^{\circ}-21^{\circ} 45^{\prime} \mathrm{N}\right)$. The geology has been compiled in ArcGIS through an interpretation of all the information available in the literature and integrated with our own geologic mapping. Published maps were digitized from printed copies; when possible, the location of features with clear morphological expression was corrected using digital elevation models within the GIS. The map includes 36 geologic units, faults, volcanic vents, and calderas. The informal geologic units used in the compilation are chronostratigraphic and lithologic and were designed to emphasize the main volcanic episodes that make up this volcanic province. The age assignment for each unit has been cross-checked with a geochronologic database that includes 2009 ages, which can be displayed on the map with access to their attributes. Lithology of each polygon has been also checked against a large geochemical database compiled from the literature.
\end{abstract}

Keywords: Central Mexico; Trans-Mexican Volcanic Belt; Digital geologic map

\section{Resumen}

En este trabajo se presenta el primer mapa geológico digital interactivo de la Faja Volcánica Transmexicana (FVTM). El área cubierta por la cartografía geológica abarca $10^{\circ}$ de longitud $\left(106^{\circ}-96^{\circ} \mathrm{W}\right)$ y $2^{\circ} 45^{\prime}$ de latitud $\left(19^{\circ}-21^{\circ} 45^{\prime} \mathrm{N}\right)$. La geología ha sido compilada en ArcGIS a través de una interpretación de toda la información disponible en la literatura e integrada con nuestra propia cartografía geológica. Los mapas publicados fueron digitalizados a partir de copias impresas; cuando fue posible se corrigió la ubicación de los rasgos con una clara expresión morfológica utilizando modelos de elevación digital en el SIG. El mapa incluye 36 unidades geológicas, fallas, chimeneas volcánicas y calderas. Las unidades geológicas informales utilizadas son cronoestratigráficas y litológicas y están diseñadas para destacar los principales episodios volcánicos que conforman el cinturón volcánico. La asignación de la edad para cada unidad ha sido cotejada con una base de datos geocronológicos que incluye 2009 edades. La clasificación litológica de cada polígono ha sido comparada por consistencia con una base de datos geoquímicos recopilados de la literatura.

Palabras clave: México central; Faja Volcánica Trans-Mexicana; Mapa geológico digital

(c) L. Ferrari, T. Orozco Esquivel, M. Navarro, P. López-Quiroz, L. Luna. Published by Terra Digitalis.

This is an Open Access article distributed under the terms of the Creative Commons Attribution License (https://creativecommons.org/licenses/by-nc-sa/4.0/), which permits non-commencial sharing of the work and adaptions, provided the original work is properly cited and the new creations are licensed under identical terms.

*E-mail address: luca@unam.mx

\section{Introduction}

The Trans-Mexican Volcanic Belt (TMVB) is the largest Neogene volcanic arc in North America with an area of 160,000 $\mathrm{km}^{2}$ and a length of almost $1000 \mathrm{~km}$ between Latitude $18^{\circ} 30^{\prime}$ and $21^{\circ} 30^{\prime} \mathrm{N}$ in central Mexico. The irregular plateau formed by this geologic province hosts an important part of the population and industrial and agricultural activity of Mexico. Furthermore, its formation in the past 20 m.y. had a significant impact 
on climate and the evolution of biodiversity (e.g., MastrettaYanez et al., 2015). The TMVB displays several peculiarities when compared with most volcanic arcs, such as the arctransversal orientation of the main stratovolcanoes, the large compositional variation of its products, the young age of the two plates subducting in front of the arc, and the absence of seismicity associated with them beneath the arc (Ferrari et al., 2012). Because of these peculiarities, over the past 40 years the TMVB has been the focus of hundreds of studies. Geologic maps have been published for the major active stratovolcanoes and some volcanic fields or for some discrete regions (Gastil et al., 1979; Demant, 1981; Pasquaré et al., 1991; Mooser et al., 1996; Carrasco et al., 1997; Ferrari et al., 2000, 2005; GarcíaPalomo et al., 2002a, 2002b; Cortés et al., 2010; Gómez-Tuena et al., 2007; Rodríguez-Elizarrarás, 2005; Macías, 2007; Guilbauld et al., 2012; Gómez-Vasconcelos et al., 2015). However, a geologic map spanning the whole province was needed to disentangle the evolution of this volcanic province and better constrain its genesis. Here we present the first digital geologic map of the TMVB and adjoining areas of its heterogeneous basement. The area covered by the map is comprised between Longitude $106^{\circ}$ and $96^{\circ} \mathrm{W}$ and Latitude $19^{\circ}$ and $21^{\circ} 45^{\prime} \mathrm{N}$. An earlier version of the map was published in static format (PDF figure in conventional papers) in Gómez-Tuena et al. (2007) and in Ferrari et al. (2012), to which the reader is referred for a comprehensive review of the geophysics of the Mexico subduction system and the geologic and petrologic evolution of the TMVB.

\section{Methods}

The geology presented in the map has been compiled over the past 18 years by the authors with the collaboration of several graduate and undergraduate students (see the Acknowledgements section for a complete list). The first step in the process was to define a general stratigraphy at the provincial level. We defined 36 informal geologic units, 25 of which belong to the TMVB proper, whereas the rest are part of the Sierra Madre Occidental and older basement terranes. The definition of this regional stratigraphy was based on chronostratigraphic and lithologic criteria and was supported by an extensive database that was first presented in Ferrari et al. (1999) and updated continuously since then by the second author. In this work, we include 2009 isotopic ages covering the area of the map, which were compiled from the literature and publicly available thesis. This information can be consulted in the interactive version of the map. Lithology of each polygon has been also checked against a large geochemical database compiled from the literature and partly published in Gomez-Tuena et al. (2007). Subsequently, existing regional geologic maps and our unpublished cartography has been reinterpreted according to the regional stratigraphy established in the previous stage. In most cases this implied grouping two or more original units into a single unit characterized by similar lithology and age range. We also compiled faults, volcanic vents, and calderas.
The regional geologic maps used in the compilation were generally at 1:50,000 to $1: 100,000$ scale. Once georeferenced, the maps were digitized with different versions of ESRI GIS software (initially ArcView and later ArcInfo). During the digitization, the lithological classification and age assignment for each unit was cross-checked for consistency with geochronologic and geochemical databases. Digitization of paper copies and the intrinsic limitations of pre-GPS era geologic mapping introduced some spatial error, particularly in the case of features like volcanic vents and fault scarps. The location of these features has been therefore refined in the GIS using a digital elevation model as a guide. The map was eventually imported into ArcGIS to correct minor errors and for final rendering. The main sources of the initial cartographic information were as follows (Fig. 1):

- Western TMVB: Ferrari et al. (2000), original 1:250,000 and 1:50,000 scale sheets provided by the authors.

- San Pedro-Ceboruco area, Nay.: Ferrari et al. (2003), original 1:50,000 scale sheets provided by the authors.

- Colima volcanic complex: Cortés et al. (2010), published map at 1:50,000 scale.

- Jilotlán region. Jal.: Colima 1:250,000 scale map of Servicio Geológico Méxicano by Rosas Elguera et al. (2000).

- Central TMVB: Pasquaré et al. (1991), original 1:100,000 and 1:50,000 scale sheets provided by the authors.

- Sierra de Guanajuato and Querétaro area: Alaniz et al. (2001), original shapefiles provided by the authors.

- Eastern TMVB: Mooser et al. (1996), published sheets at 1:100,000 scale.

- Nevado de Toluca area: García-Palomo et al. (2002a), published map at 1:100,000 scale.

- Valle de Bravo and Zitácuaro areas: geologic maps in Blatter et al. (2001).

- Apan area, Hidalgo: geologic map in García-Palomo et al. (2002b).

- Zimapán area, Hidalgo: Carrillo-Martínez (2000), published map at 1:100,000 scale.

- Cerro Grande and surroundings, Puebla: Carrasco-Núñez et al. (1997), published map at 1:100,000 scale.

- Easternmost TMVB: Ferrari et al. (2005), original 1:50,000 scale sheets provided by the authors.

In some cases, information of the original maps was updated according to field data and unpublished mapping by Ferrari and Orozco, which also served as a base for areas not covered by the above maps. 


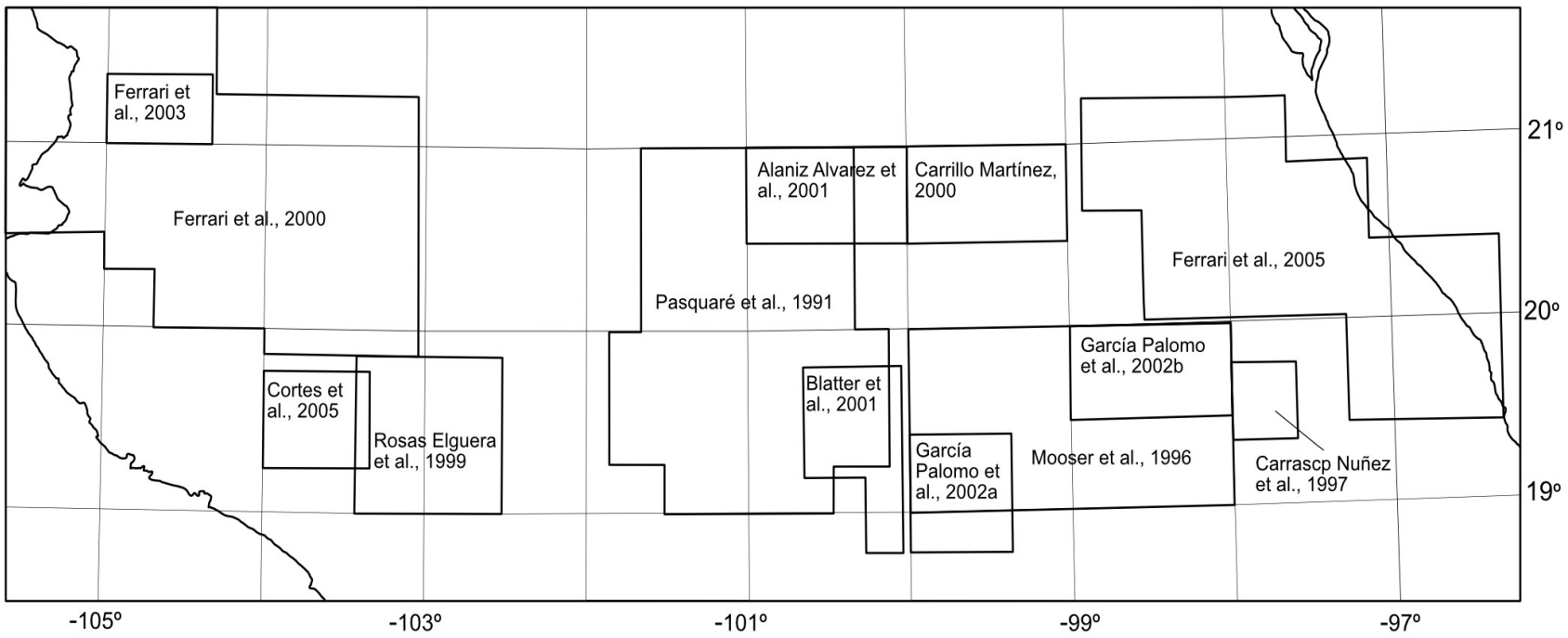

Figure 1. Main sources of the initial cartographic information Figura 1. Principales fuentes de la información cartográfica inicial.

\section{Map units}

All geologic units used in the map are informal and were established with the aim of correlating volcanic episodes throughout the TMVB. They can be divided in to two broad groups: a) rocks that precede the onset of the TMVB, and 2) rocks belonging to the TMVB volcanic activity and associated continental sedimentary basins. The TMVB group can be further subdivided according to the four volcanic episodes described in Ferrari et al. (2012). Rocks pre-dating the TMVB belong to the Sierra Madre Occidental, the Laramide arc, the Sierra Madre Oriental and the Guerrero terrane. Table 1 (see Appendix A) summarizes each map unit under this scheme. See Plate 1 for a PDF version of the map.

\section{Acknowledgements}

The TMVB GIS has been elaborated by Luca Ferrari and Teresa Orozco-Esquivel with the collaboration of T. NoratoCortez, N. González-Cervantes, M. Hernández-Ramírez, A. Rossotti, V.M. Reyes-Orozco, M.G. García-Sierra, A. Silva Fragoso and V. Martínez Reséndiz as part of undergraduate and graduate thesis or social service. J. Rosas Elguera and G. Carrasco Núñez provided geologic information for the western and eastern TMVB, respectively, in an early stage of the project. Laura Luna-González elaborated the first version of the map in ArcInfo and Mario Navarro and Penélope López-Quiroz took care of the update and the adaptation in ArcGIS. Reviews by Carlos González León and José Rosas Elguera improved the clarity of the map and the text. Javier Osorno provided a crucial support along all the editorial process.

\section{References}

Alaniz-Álvarez, S. A., Nieto-Samaniego, A. F., Reyes-Zaragoza, M. A., Orozco-Esquivel, M. T., Ojeda-García, A. C., Vassallo, L. F., 2001. Estratigrafía y deformación extensional en la región San Miguel de AllendeQuerétaro, México. Revista Mexicana de Ciencias Geológicas 18 (2), 129 148.

Blatter, D. L., Carmichael, I. S. E., Deino, A. L., Renne, P. R., 2001. Neogene volcanism at the front of the central Mexican volcanic belt: Basaltic andesites to dacites, with contemporaneous shoshonites and high-TiO2 lava. Geological Society of America Bulletin 113 (10), 1324-1342, doi: 10.1130/0016-7606(2001)113<1324:NVATFO > 2.0.CO;2.

Carrasco-Núñez, G., Gómez-Tuena, A., Lozano, L., 1997. Geologic map of Cerro Grande volcano and surrounding area, Central Mexico. Geological Society of America, Maps and Charts Series, MCH 089, 1 map, 26 pp. text.

Carrillo-Martínez, M., 2000. Geología de la Hoja 14Q-e(7) Zimapán, Estados de Hidalgo y Querétaro: México, D.F. Universidad Nacional Autónoma de México, Instituto de Geología, Carta geológica de México, serie 1:100000, map explanations, $33 \mathrm{pp}$.

Cortés, A., Garduño-Monroy, V. H., Macías, J. L., Navarro-Ochoa, C., Komorowski, J. C., Saucedo, R., Gavilanes, J. C., 2010. Geologic mapping of the Colima volcanic complex (Mexico) and implications for hazard assessment. Geological Society of America 464, 249-264, doi:doi.org/10.1130/2010.2464(12).

Cortés, A., Garduño-Monroy, V. H., Navarro-Ochoa, C., Saucedo, R., Macias, J. L., Gavilanes, J. C., 2005. Geología del complejo volcánico de Colima, UNAM, Instituto de Geología, Cartas Geológicas y Mineras 10, escala 1:100,000. Mapa con texto explicativo, $37 \mathrm{p}$.

Demant, A., 1981. L'axe neovolcanique transmexicain: etude volcanique et petrographique, signification geodynamique. Marseille, France, Université de Droit, d'Economie et de Sciences d'Aix-Marseille (Doctoral dissertation, $259 \mathrm{pp})$.

Ferrari, L., López-Martínez, M., Aguirre-Díaz, G., Carrasco-Núñez, G., 1999. Space-time patterns of Cenozoic arc volcanism in central Mexico: From the Sierra Madre Occidental to the Mexican Volcanic Belt. Geology 27 (4), 303-306, doi:10.1130/0091-7613(1999)027<0303:STPOCA >2.3.CO;2.

Ferrari, L., Orozco-Esquivel, T., Manea, V., Manea, M., 2012. The dynamic history of the Trans-Mexican Volcanic Belt and the Mexico subduction zone. Tectonophysics 522-523, 122-149, doi:10.1016/j.tecto.2011.09.018.

Ferrari, L., Pasquarè, G., Venegas-Salgado, S., Romero-Rios, F., 2000. Geology 
of the western Mexican Volcanic Belt and adjacent Sierra Madre Occidental and Jalisco Block. in Delgado- Granados, H., Aguirre-Díaz, G., Stock, J. (Eds.), Cenozoic Tectonics and Volcanism of Mexico: Geological Society of America Special Paper, 334, 65-84.

Ferrari, L., Petrone, C. M., Francalanci, L., Tagami, T., Eguchi, M., Conticelli, S., Manetti, P., Venegas-Salgado, S., 2003. Geology of the San Pedro Ceboruco Graben, western Trans-Mexican Volcanic Belt. Revista Mexicana de Ciencias Geológicas 20 (3), 165-181.

Ferrari, L., Tagami, T., Eguchi, M., Orozco-Esquivel, M. T., Petrone, C. M., Jacobo-Albarrán, J., López-Martínez, M., 2005. Geology, geochronology and tectonic setting of late Cenozoic volcanism along the southwestern Gulf of Mexico: The Eastern Alkaline Province revisited. Journal of Volcanology and Geothermal Research 146 (4), 284-306, doi:10.1016/j.jvolgeores.2005.02.004.

García-Palomo, A., Macías, J. L., Arce, J. L., Capra, L., Garduño, V. H., Espíndola, J. M., 2002a. Geology of the Nevado de Toluca volcano and surrounding areas, Central Mexico: Geological Society of America, Maps and Charts Series, MCH080, 1 map, 26 pp. text.

García-Palomo, A., Macías, J. L., Tolson, G., Valdez, G., Mora, J. C., 2002 b. Volcanic stratigraphy and geological evolution of the Apan region, eastcentral sector of the Trans-Mexican Volcanic Belt. Geofísica Internacional 41 (2), 133-150.

Gastil, G., Krummenacher, D., Minch, J., 1979. The record of Cenozoic volcanism around the Gulf of California. Geological Society of America Bulletin 90(9), 839-857.

Guilbaud, M. N., Siebe, C., Layer, P., Salinas, S., 2012. Reconstruction of the volcanic history of the Tacámbaro-Puruarán area (Michoacán, México) reveals high frequency of Holocene monogenetic eruptions. Bulletin of Volcanology 74 (5), 1187-1211, doi:10.1007/s00445-012-0594-0.

Gómez-Tuena, A., Orozco-Esquivel, M. T., Ferrari, L., 2007. Igneous petrogenesis of the Trans-Mexican Volcanic Belt, in Alaniz-Álvarez, S.A., NietoSamaniego, Á.F. (Eds.), Geology of México: celebrating the Centenary of the Geological Society of México. Geological Society of America Special Paper 422, 1-53, doi: 10.1130/2007.2422(05).

Gómez-Vasconcelos, M. G., Garduño-Monroy, V. H., Macías, J. L., Layer, P. W., Benowitz, J. A., 2015. The Sierra de Mil Cumbres, Michoacán, México: Transitional volcanism between the Sierra Madre Occidental and the Trans-Mexican Volcanic Belt. Journal of Volcanology and Geothermal Research 301, 128-147, doi:10.1016/j.jvolgeores.2015.05.005.

Macías, J. L., 2007. Geology and eruptive history of some active volcanoes of México. Geological Society of America Special Paper 422, 183-232, doi: 10.1130/2007.2422(06).

Mastretta-Yanes, A., Moreno-Letelier, A., Piñero, D., Jorgensen, T. H., Emerson, B., 2015. Biodiversity in the Mexican highlands and the interaction of geology, geography and climate within the Trans-Mexican Volcanic Belt. Journal of Biogeography 42 (9), 1586-1600, doi:10.1111/jbi.12546.

Mooser, F., Montiel, A., Zúñiga, A., 1996. Nuevo mapa geológico de las cuencas de México, Toluca y Puebla: estratigrafía, tectónica regional y aspectos geotérmicos: Mexico, D.F., Comisión Federal de Electricidad, 27 pages, 36 leaves of plates.

Pasquaré, G., Ferrari, L., Garduño, V., Tibaldi, A., Vezzoli, L., 1991. Geology of the central sector of the Mexican Volcanic Belt, States of Guanajuato and Michoacan: Geological Society of America, Maps and Charts Series, MCH072, scale 1:300 000, 1 sheet, 22 pp. text.

Rodríguez-Elizarrarás, S. R., 2005. Geology of Las Cumbres Volcanic Complex, Puebla and Veracruz states, Mexico. Revista Mexicana de Ciencias Geológicas 22(2), 181-199. 


\section{Geologic map of the Trans-Mexican Volcanic Belt}

Luca Ferrari ${ }^{1}$, Teresa Orozco ${ }^{1}$, Mario Navarro ${ }^{1}$, Penélope López-Quiroz ${ }^{1}$, Laura Luna ${ }^{2}$. 'Centro de Geociencias, UNAM, 'Instituto de Geología, UNAM

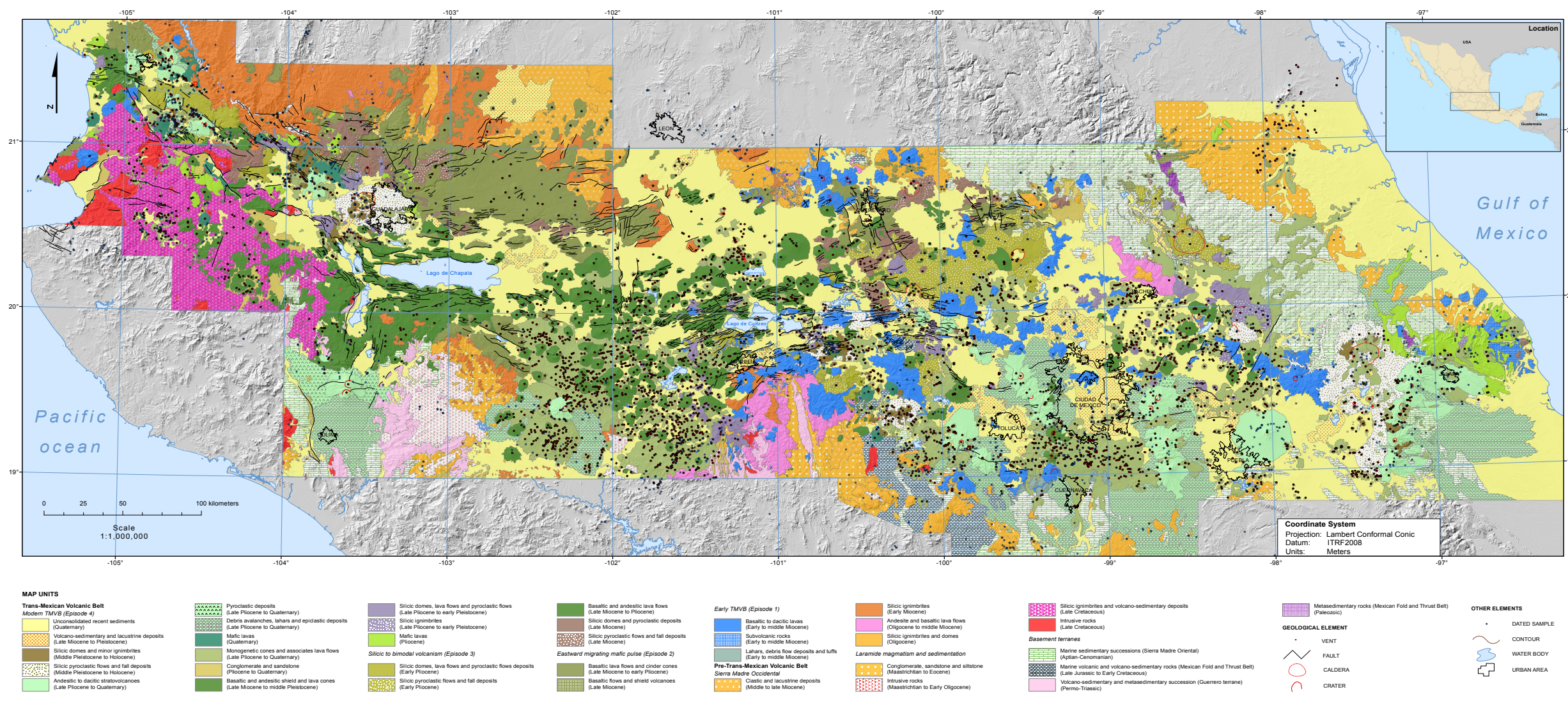


Appendix A. Table 1. Description of maps units (Tabla 1. Descripción de las unidades del mapa)

\begin{tabular}{|c|c|c|}
\hline Map unit & Age & Description \\
\hline \multicolumn{3}{|c|}{ Trans-Mexican Volcanic Belt } \\
\hline \multicolumn{3}{|l|}{ Modern TMVB (Episode 4) } \\
\hline Unconsolidated recent sediments & Quaternary & $\begin{array}{l}\text { Uppermost, recent alluvial and lacustrine deposits, } \\
\text { mostly undergoing sedimentation. }\end{array}$ \\
\hline Volcano-sedimentary and lacustrine deposits & Late Miocene to Pleistocene & $\begin{array}{l}\text { Volcano-sedimentary and lacustrine deposits filling } \\
\text { basins bounded by tectonic or volcanic structures. In } \\
\text { some cases, under active erosion. }\end{array}$ \\
\hline Silicic domes and minor ignimbrites & Middle Pleistocene to Holocene & $\begin{array}{l}\text { Effusive rhyolitic volcanism and related pyroclastic } \\
\text { deposits, associated to calderas (La Primavera, Los } \\
\text { Humeros) or part of fault controlled dome clusters } \\
\text { (Tequila area). }\end{array}$ \\
\hline Silicic pyroclastic flows and fall deposits & Middle Pleistocene to Holocene & $\begin{array}{l}\text { Large volume rhyolitic ignimbrites associated to } \\
\text { caldera forming eruptions (La Primavera, Los Azufres, } \\
\text { Zitácuaro, Acoculco, Los Humeros, La Cumbre). }\end{array}$ \\
\hline Andesitic to dacitic stratovolcanoes & Late Pliocene to Quaternary & $\begin{array}{l}\text { Main stratovolcanoes of the TMVB formed by alternating } \\
\text { effusive and explosive volcanic activity with subduction- } \\
\text { related character. From W to E they include: San } \\
\text { Juan, Sangangüey, Tepetiltic, Ceboruco, Tequila, Tancí- } \\
\text { taro, Temascalcingo, Jocotitlán, San Antonio, Nevado de } \\
\text { Toluca, Popocatépetl, Iztaccíhuatl, Telapón, Malinche, } \\
\text { Pico de Orizaba, and Cofre de Perote volcanoes, as well } \\
\text { as the Colima and Sierra de Las Cruces volcanic com- } \\
\text { plexes. }\end{array}$ \\
\hline Pyroclastic deposits & Late Pliocene to Quaternary & $\begin{array}{l}\text { Pyroclastic flows and fall deposits associated to major } \\
\text { explosive eruptions of the main stratovolcanoes of the } \\
\text { TMVB. }\end{array}$ \\
\hline Debris avalanches, lahars and epiclastic deposits & Late Pliocene to Quaternary & $\begin{array}{l}\text { Mass-wasting deposits associated to major explosive } \\
\text { eruptions of the main stratovolcanoes of the TMVB. }\end{array}$ \\
\hline Mafic lavas & Quaternary & $\begin{array}{l}\text { Fissure-fed basaltic lava plateaus and small cinder cones } \\
\text { associated with extensional fault systems; mostly with in- } \\
\text { traplate affinity and located in the western and eastern } \\
\text { parts of the TMVB. }\end{array}$ \\
\hline Monogenetic cones and associates lava flows & Late Pliocene to Quaternary & $\begin{array}{l}\text { Cinder cones and lavas flows mostly with subduction- } \\
\text { related character, which may be associated to extensional } \\
\text { fault systems. Sometimes forming large fields such as the } \\
\text { Michocán-Guanajuato and Chichinautzin volcanic fields. }\end{array}$ \\
\hline Conglomerate and sandstone & Pliocene to Quaternary & $\begin{array}{l}\text { Clastic sedimentary deposits filling tectonic basins, } \\
\text { mostly in the western TMVB. }\end{array}$ \\
\hline Basaltic and andesitic shield and lava cones & Late Miocene to middle Pleistocene & $\begin{array}{l}\text { Polygenetic volcanoes with dominant effusive activ- } \\
\text { ity and subduction-related character. Mostly in the } \\
\text { Michoacán-Guanajuato and Apan volcanic fields. }\end{array}$ \\
\hline Silicic domes, lava flows and pyroclastic flows & Late Pliocene to early Pleistocene & $\begin{array}{l}\text { Effusive rhyolitic volcanism and associated pyroclastic } \\
\text { deposits (W TMVB, Michoacán-Guanajuato VF, Villa } \\
\text { Madero, Los Azufres, Apan, Tulancingo, Las Navajas). }\end{array}$ \\
\hline Silicic ignimbrites & Late Pliocene to early Pleistocene & $\begin{array}{l}\text { Large volume explosive volcanism associated to caldera- } \\
\text { forming eruptions (Acoculco). }\end{array}$ \\
\hline Mafic lavas & Pliocene & $\begin{array}{l}\text { Fissure-fed basaltic lavas and small lava cones in part as- } \\
\text { sociated with normal faults, mostly with intraplate affin- } \\
\text { ity and located in the western and eastern parts of the } \\
\text { TMVB. }\end{array}$ \\
\hline
\end{tabular}

Silicic to bimodal volcanism (Episode 3)

Silicic domes, lava flows and pyroclastic flows de- Early Pliocene posits

Silicic pyroclastic flows and fall deposits

Early Pliocene

Basaltic and andesitic lava flows

Late Miocene to Pliocene
Effusive rhyolitic volcanism and associated low-volume pyroclastic deposits. In the western TMVB these rocks are not associated with calderas.

Large volume ignimbrites often from caldera-forming eruptions (Ciudad Hidalgo, Amealco, Huichapan, Carbonera).

Fissure-fed lava flows, cinder cones and mid-sized lava cones with dominantly subduction-related character. Mostly in the western and central TMVB. 
Silicic domes and pyroclastic deposits

Silicic pyroclastic flows and fall deposits

Eastward migrating mafic pulse (Episode 2)

Basaltic lava flows and cinder cones

Basaltic flows and shield volcanoes

Late Miocene
Effusive rhyolitic volcanism and associated low volume pyroclastic deposits. Chiefly located in the Guadalajara and Querétaro regions.

Large volume ignimbrites sometimes from caldera forming eruption (Amazcala).

\section{Early TMVB (Episode 1)}

Basaltic to dacitic lavas

Subvolcanic rocks

Lahars, debris flow deposits and tuffs

Early to middle Miocene
Mafic lava flows and cinder cones with intraplate affinity of the north-eastern TMVB.

Fissure fed mafic lava flows and small shield volcanoes showing migration from $\mathrm{W}$ to $\mathrm{E}$ (NW of Tepic, San Cristobal, Altos de Jalisco, Cotija region, QuerétaroPathé region).

\begin{tabular}{|c|c|c|}
\hline \multicolumn{3}{|c|}{ Pre-Trans-Mexican Volcanic Belt } \\
\hline \multicolumn{3}{|l|}{ Sierra Madre Occidental } \\
\hline Clastic and lacustrine deposits & Middle to late Miocene & $\begin{array}{l}\text { Conglomerate, sandstone and lacustrine deposits filling } \\
\text { large basins, mostly north of the TMVB (e.g. Teo- } \\
\text { caltiche, San Juan de los Lagos). }\end{array}$ \\
\hline Silicic ignimbrites & Early Miocene & $\begin{array}{l}\text { Large volume ash flow deposits of the second pulse of } \\
\text { silicic volcanism of the Sierra Madre Occidental. They } \\
\text { are found also south of the TMVB in the Cotija and Mil } \\
\text { Cumbres regions. }\end{array}$ \\
\hline Andesite and basaltic lava flows & Oligocene to middle Miocene & $\begin{array}{l}\text { Mafic lava flows capping or intercalated in the upper part } \\
\text { of the SMO ignimbrite, often showing an intraplate affin- } \\
\text { ity. Basaltic and andesitic lava flows in the Tzitzio-Mil } \\
\text { Cumbres and Pachuca-Real del Monte regions. }\end{array}$ \\
\hline Silicic ignimbrites and domes & Oligocene & $\begin{array}{l}\text { Large volume ash flow deposits and rhyolitic domes of } \\
\text { the first pulse of silicic volcanism of the Sierra Madre Oc- } \\
\text { cidental. Located north and south of the eastern TMVB. }\end{array}$ \\
\hline \multicolumn{3}{|l|}{ Laramide magmatism and sedimentation } \\
\hline Conglomerate, sandstone and siltstone & Maastrichtian to Eocene & $\begin{array}{l}\text { Clastic continental deposits. South of the TMVB they } \\
\text { correspond to red beds of the Cutzamala Formation. }\end{array}$ \\
\hline Intrusive rocks & Maastrichtian to Early Oligocene & $\begin{array}{l}\text { Granitic to dioritic rocks of the Jilotlán and La Huacana } \\
\text { plutons. }\end{array}$ \\
\hline Silicic ignimbrites and volcano-sedimentary deposits & Late Cretaceous & $\begin{array}{l}\text { Ash flow deposits, andesitic lava flows and breccias } \\
\text { within the Jalisco Block. }\end{array}$ \\
\hline Intrusive rocks & Late Cretaceous & $\begin{array}{l}\text { Granite, granodiorite and diorite of the Puerto Vallarta } \\
\text { batholith. }\end{array}$ \\
\hline \multicolumn{3}{|l|}{ Basement terranes } \\
\hline $\begin{array}{l}\text { Marine sedimentary successions (Sierra Madre Ori- } \\
\text { ental) }\end{array}$ & Aptian-Cenomanian & $\begin{array}{l}\text { Limestone, argillite, slate and sandstone. In the Tejupilco } \\
\text { area they show intercalation of pillow lavas. }\end{array}$ \\
\hline $\begin{array}{l}\text { Marine volcanic and volcano-sedimentary rocks } \\
\text { (Mexican Fold and Thrust Belt) }\end{array}$ & Late Jurassic to Early Cretaceous & $\begin{array}{l}\text { Sandstone, shales and minor limestone interbedded with } \\
\text { volcanic rocks. Mostly exposed in the Sierra de Los } \\
\text { Cuarzos. }\end{array}$ \\
\hline $\begin{array}{l}\text { Volcano-sedimentary and metasedimentary succes- } \\
\text { sion (Guerrero terrane) }\end{array}$ & Permo-Triassic & $\begin{array}{l}\text { Low to medium grade metamorphic succession of the } \\
\text { Guerrero terrane mostly exposed in the Tejupilco and Tz- } \\
\text { itzio anticlinorium (correlative with the Arteaga Com- } \\
\text { plex). }\end{array}$ \\
\hline $\begin{array}{l}\text { Metasedimentary rocks (Mexican Fold and Thrust } \\
\text { Belt) }\end{array}$ & Paleozoic & $\begin{array}{l}\text { Meta-sandstone and -shales of the Huayacocotla anti- } \\
\text { cline. }\end{array}$ \\
\hline
\end{tabular}


This article accompanies the following material:

HTML:

Static map:

Interactive map:
DOI: 10.22201/igg.terradigitalis.2018.1.34.84

DOI: 10.22201/igg.terradigitalis.2018.1.34.93

DOI: 10.22201/igg.terradigitalis.2018.1.34.94 